\title{
Tiede politiikan tueksi
}

Tieteen ja politiikan suhteissa on kaksi erilaista tavoitetta. Tiedepolitiikalla tarkoitetaan valtion tai monikansallisen yhteisön (EU, YK) toimia tieteen ja innovaatiotoiminnan edistämiseksi (policy for science). Se pitää sisällään tiedestrategiat, kansainväliset sopimukset, tutkimusrahoituksen mahdollisine ohjelmineen ja priorisointeineen, tutkijoiden liikkuvuutta edistävät toimet ym. Suomessa tiedepolitiikka on valtion tiede- ja teknologianeuvoston (TIN) ohjauksessa, ja käytännön toteutuksesta vastaa lähinnä Suomen Akatemia.

Toinen lähestymiskulma on tutkitun tiedon käyttö tukemaan yhteiskunnan päätöksentekoa laajemmin, ei vain tieteen hyväksi (science for policy). Tiedeneuvonta tulee yhä tärkeämmäksi, kun tiede ja teknologia muuttavat yhteiskuntia ja ihmisten elämää, ja poliitikot joutuvat ratkomaan yhä viheliäisempiä ongelmia. Tiedeneuvonnan käytännöt ja organisaatiorakenteet ovat meillä vielä kehittymättömät (1). Tarkastelen tässä kirjoituksessa tiedeneuvonnan nykytilannetta ja mahdollisia kehityssuuntia, pääosin terveydenhuoltoon liittyvien esimerkkien valossa.

\section{PÄÄTÖKSENTEON PERUSTEET}

Me ihmiset teemme päätöksiä pääosin intuitiivisesti, aikaisempien kokemusten ja erilaisten nyrkkisääntöjen perusteella, ilman syvällistä pähkäilyä tai asia-argumenttien etsimistä. Sellaista tarvitaan vasta tilanteissa, joissa pitää keskittyä, tehdä valintoja tai laskutoimituksia, tai korjata intuition tuottamia möhläyksiä (2).

Kuitenkin sekä yksilön että yhteiskunnan päätöksenteon taustalla on monia muitakin motiiveja kuin maalaisjärki ja tutkittu tieto. Arvot ja ideologiat ohjaavat vahvasti etenkin uskonnon ja politiikan kentillä, talouden realiteetit ja auktoriteettien mielipiteet muokkaavat päätöksiä, ja usein mennään vain joukon mukana kuin sopulit. Tutkittu tieto tarjoaa kuitenkin tukevimman pohjan päätöksille, koska se hankitaan koetuilla menetelmillä, testataan vertaisarvioinnin myl- lyssä, ja varmennetaan tai kumotaan toisten tutkijoiden toimesta. Näin tutkimustieto korjaa itseään ja lähestyy todenmukaista kuvaa luonnosta, ihmisestä ja yhteiskunnasta, vaikka täydellistä varmuutta harvoin saavutetaan.

Valtakunnan ylimmässä päätöksentekoelimessä, eduskunnassa, kansanedustajan tulee noudattaa oikeutta ja totuutta, ja toimessaan häntä sitoo perustuslaki, eivät muut määräykset. Kuitenkin yksi "muu määräys" voi estää perustuslain mukaisen äänestyskäyttäytymisen, nimittäin puoluekuri. Sen koki karvaasti terveydenhuollon huippuasiantuntija, Terveyden ja hyvinvoinnin laitoksen (THL) entinen pääjohtaja, kansanedustaja Pekka Puska. Hän oli julkisesti ja hyvin perustein ilmoittanut kannattavansa täyden päivystyksen oikeuksia Vaasan keskussairaalalle, mutta joutui puolueensa Keskustan jyräämänä painamaan ei-nappia Vaasalle ja kyllä Seinäjoelle. Koko kiista oli turha, sillä asiantuntija-arviot eivät tarjonneet mitään perusteita sille, että päivystyssairaaloita tulee olla juuri 12 eikä esimerkiksi 13.

\section{POLIITTISEN PROSESSIN PYÖRTEET}

Monimutkaisessa maailmassa muuttuvan ja kehittyvän yhteiskunnan tarpeet ja toiveet ovat moninaiset ja usein ristiriitaiset. Eduskuntavaalien jälkeen puolueiden ohjelmat ja vaalilupaukset muuntuvat hallitusneuvotteluissa kompromissien kautta politiikan asialistaksi nimeltään hallitusohjelma. Se on tärkein valtioneuvoston ja eduskunnan työtä ohjaava dokumentti seuraavien neljän vuoden ajan. Sieltä poimitaan ne asiat, joiden katsotaan edellyttävän lakien tai asetusten valmistelua, budjetin tekoa tai muuta hallinnollista ohjausta.

Ministeriöiden virkamiesten vastuulla on uuden hankkeen lähtötilanteen analyysi, mahdollisten toimintavaihtoehtojen sekä niihin liittyvien riskien kartoitus, valitun toimintalinjan vaikutusten arviointi ja säädösten sekä niiden peruste- 
lujen muokkaus. Esitys menee sitten eduskunnan päätösprosessiin, mutta säädösten vaikutuksia täytyy vielä arvioida ja tarvittaessa hienosäätää. Selvää on, että luotettavaa tietoa tarvitaan päätöksenteon pohjaksi monessa prosessin vaiheessa (3).

Etenkin sosiaali- ja terveydenhuollon kentässä kunnilla ja kuntayhtymillä on vähintään yhtä tärkeä rooli kuin valtakunnan tason päätöksenteolla. Satojen kooltaan ja vauraudeltaan hyvin erilaisten kuntien virka- ja luottamushenkilöt tekevät päätöksiä budjeteista, investoinneista ja kilpailutetuista hankinnoista usein varsin vajavaisen tiedon ja osaamisen pohjalta. Kuntayhtymien päättävissä elimissä istuvat henkilöt eivät yleensä edusta poliittisen rälssin kärkeä, mutta ovat tavallaan kaksinkertaisia panttivankeja. Kotikunta ja puolue tulevat ensin, kuntayhtymän etu vasta sen jälkeen. Korviin kuiskuttelevat monien etujärjestöjen ja yritysten lobbarit. Budjetit ovat aina kireät ja säästää pitää, mutta toimintaa on silti pyöritettävä. Näin ollen investoinneista nipistetään ja korjausrakentamista lykätään. Tässä lienee yksi tärkeä syy esimerkiksi siihen, että sairaalarakennukset pääsevät rapistumaan.

\section{MISTÄ LUOTETTAVA TIETO?}

Näyttöön perustuvan päätöksenteon (evidencebased policy) kokonaisuuteen kuuluvat tiedon tuottajat, välittäjät ja loppukäyttäjät.

Suomi tuottaa vain noin 0,6 prosenttia maailman tieteestä. Yliopistojen ja tutkimuslaitosten merkitys on kuitenkin paljon tätä suurempi, koska niiden aktiiviset tutkijat avaavat portit koko maailman aikaansaannoksiin. Yliopistoilla on kuitenkin perustuslain turvaama autonomia sekä tieteen ja opetuksen vapaus. Niillä ei ole perinteitä eikä myöskään kannustimia tuottaa tietoa yhteiskunnan erilaisia intressejä palvelemaan.

Valtion sektoritutkimuslaitoksia ei ole läheskään kaikilla hallinnonaloilla eivätkä ne ole riittävästi tuoneet asiantuntemusta päätöksenteon tueksi. Siitä ministeriöt saavat syyttää itseään, koska niillä on tulosohjausvastuu tutkimuslaitoksista. Puutteiden korjaamiseksi vuoden 2013 uudistuksessa tutkimuslaitoksia yhdistettiin ja niiden budjeteista siirrettiin liki kolmannes uuteen strategisen tutkimuksen rahastoon, jonka priorisoinnit päättää valtioneuvosto ja byrokratian hoitaa Suomen Akatemia. Nähtäväksi jää, tuottaako tällainen "top-down" -ohjaus kunnol- lista tutkimustietoa vai konsulttiyritysten rutiiniselvityksiä.

Elinkeinoelämä harjoittaa julkista sektoria laajempaa tutkimustoimintaa, mutta pitää tulokset yleensä omana tietonaan.

Tutkimusmaailman ja yhteiskunnan rajapinnassa toimii iso joukko organisaatioita, jotka välittävät tietoa päätöksentekijöille. Asiantuntijapaneelit kokoavat systemaattisesti tietystä aiheesta julkaistun tutkimustiedon, arvioivat kriittisesti sen luotettavuuden ja laativat siitä yleistajuisen tiivistelmän. Näin toimii hallitusten välinen ilmastopaneeli (IPCC), jonka raportit ovat nykyisin sekä kansainvälisen että kansallisen poliittisen kädenväännön ytimessä (4). Ympäristöministeriön piirissä toimivat kansalliset ilmasto- ja luonnon monimuotoisuus (IPBES) -paneelit. Vastaavaa periaatetta toteuttaa Lääkäriseura Duodecimin alulle panema Käypä hoito -projekti, joka tuottaa tutkittuun tietoon perustuvia hoito-ohjeita terveydenhuollon tarpeisiin (5). Monien asiantuntijoiden yhteinen kanta on luotettavampi kuin yhden henkilön käsitys. Vertaisarviointi on perinne tiedeyhteisössä, joka kokemuksen mukaan osallistuu mielellään systemaattisten katsausten laadintaan.

Tiedon välittäjäorganisaatioihin kuuluu myös epämääräinen joukko ajatuspajoja sekä konsultti- ja viestintäyrityksiä, joita voisi kutsua yhteisnimellä lobbarit. Puolueiden ajatuspajoja lukuunottamatta ne toimivat kaupallisella pohjalla ja ovat riippuvaisia toimeksiantajan rahoituksesta. Monet ovat menestyksellä rekrytoineet leipiinsä jopa ministeritason poliittisia konkareita, joten kanavat päätöksenteon huipulle lienevät auki.

Tiedon loppukäyttäjistä sekä virkamiesten että poliitikkojen mahdollisuudet hankkia ja hyödyntää tutkittua tietoa ovat sattumanvaraiset ja puutteelliset. Vain harvoilla on itsellään tutkijan koulutus ja kyky tiedon kriittiseen arviointiin. Myös avustajakaarti on yleensä pätevöitynyt muita reittejä, ja kontaktit tiedeyhteisöön ovat ohuet. Useimmille Google lienee tavallisin viisauden lähde, mutta verkko tulvii laadullisesti erittäin kirjavaa, usein virheellistä "tietoa". Wikipedia on kuitenkin mainettaan parempi sisällön laadun suhteen.

Haastattelujen perusteella (3) puoluejohtajat ja kansanedustajat pitävät tärkeänä, että tutkimustietoa käytetään nykyistä enemmän päätök- 
senteon perustana. Samaa mieltä ovat kansalaiset, jotka Tiedebarometrin (6) mukaan luottavat yliopistoihin ja tiedeyhteisöön enemmän kuin moniin muihin yhteiskunnan instituutioihin (kirkko, media, eduskunta, poliittiset puolueet).

\section{SOTE-UUDISTUS - PÄÄTÖKSENTEKOPROSESSIEN UMPIKUJA}

Jo vuosia on tiedetty, että Suomen sosiaali- ja terveydenhuoltojärjestelmä on uudistettava. Siinä on yksi toimiva osa, nimittäin erikoissairaanhoito, jonka tulokset ja kustannustehokkuus kestävät vertailun minkä tahansa maan kanssa. Sen järjestämisvastuu on kuntien muodostamilla sairaanhoitopiireillä, joita on 20, ja vaativimmissa tapauksissa viiden yliopistosairaalan erityisvastuualueilla. Sen sijaan kuntien vastuulla olevan perusterveydenhuollon osalta kansalaiset ovat eriarvoisessa asemassa, ja integraatio koko sotejärjestelmässä ei toimi. Lisäksi väen vanhetessa kustannukset uhkaavat viedä monia pieniä kuntia konkurssiin.

Vuoden 2015 vaalien jälkeen Juha Sipilän hallitus otti sote-uudistuksen päätavoitteekseen. Aikaisemmat yritykset ja alueelliset kokeiluhankkeet olisivat antaneet pohjaa toimivan järjestelmän suunnittelulle. Sen sijaan lähdettiin rakentamaan massiivista lakipakettia, jonka kahta keskeistä osaa tarvittiin ainoastaan kahden päähallituspuolueen, ei sote-uudistuksen, intressien toteuttamiseksi. Keskustapuolue halusi palauttaa vajaat kymmenen vuotta sitten puretun väliportaan hallinnon, jotta 18 maakuntaa vahvistaisi puolueen asemia tyhjenevillä haja-asutusalueilla. Kokoomus halusi valinnanvapauden varjolla avata terveydenhuollon markkinat yksityisille toimijoille. Koko paketti osoittautui mahdottomaksi ratkaista aikataulussa, jonka lähestyvät vaalit kiristivät äärimmilleen. Niinpä pääministerin "tulos tai ulos" -periaatteen mukaisesti hallitus joutui eroamaan juuri ennen kevään 2019 vaaleja.

Koko prosessissa tehtiin useita raskaita virheitä, joista olisi syytä ottaa oppia. Sosiaali- ja terveysministeriö on vahva asiantuntijaorganisaatio, jonka henkilöstössä on enemmän tohtorin tutkinnon suorittaneita (noin 40) kuin missään muussa ministeriössä. THL omaa parhaan tutkimustiedon suomalaisten terveydestä ja terveydenhuoltojärjestelmän toiminnasta. Lisäksi sote-lakien valmistelussa käytettiin monia ulko- puolisia asiantuntijoita ja asetettiin seurantaryhmä. Silti päädyttiin kaoottiseen tilanteeseen, asiantuntijat kiistelivät keskenään, ja poliittinen diktaatti jyräsi tutkitun tiedon. Näyttöön perustuvan päätöksenteon (evidence-based policy) asemesta pyrittiin jopa ohjaamaan tutkimuslaitosta tuottamaan valittuja ratkaisuja tukevaa tietoa (policy-based evidence).

\section{KUKA ON ASIANTUNTIJA?}

Asiantuntija- sana antaa vaikutelman luotettavuudesta. Oikeudenkäymiskaaren mukaan "asiantuntijan on oltava rehelliseksi ja alallaan taitavaksi tunnettu”. Epäselväksi jää, kuinka tästä rehellisyydestä ja taitavuudesta tulisi varmistua. Vaikka rehellisyyttä on vaikea opettaa, niin taitavuutta eri aloilla voi hankkia koulutuksen kautta. Hyvän oppilaitoksen antama tutkintotodistus osoittaa ainakin kykyä hankkia ja käyttää tietoa, joskin kelvottomia koulutusyksiköitä ja väärennettyjä todistuksia on myös liikkeellä. Työkokemus on arvokas tapa pätevöityä asiantuntijaksi, samoin tutkimustyö, johon kuitenkin pätee Nobel-fyysikko Niels Bohrin määritelmä: "Asiantuntija on henkilö, joka on tehnyt kaikki mahdolliset virheet hyvin kapealla alueella”. Julkisuuteen pyrkii myös kansalaisia, jotka ovat itse julistautuneet asiantuntijoiksi joko omien kokemustensa tai sisäisen valaistumisen perusteella. Yhden henkilön kokemus ei kuitenkaan ole yleistettävissä, eikä sitkeissä yhden asian ajajissa ole helppo herättää edes alkeellista itsekritiikkiä. Kuitenkin joissakin tilanteissa esimerkiksi saman vaikean sairauden läpikäynyt kokemusasiantuntija voi olla potilaalle hyvä tukihenkilö.

Lainvalmistelun taso on viime vuosina saanut moitteita niin tutkijoilta (Oikeuspoliittinen tutkimuslaitos) kuin valtionhallinnon toimintaa arvioivilta elimiltä (Eduskunnan tarkastusvaliokunta, Lainsäädännön arviointineuvosto). Ennen kaikkea on moitittu vaikutusarviointien puutteita, vallankin taloudellisten seuraamusten arviointia. Esimerkiksi sote-uudistuksen yksi päätavoite oli 3 miljardin euron vuotuinen säästö terveydenhuoltomenoissa, mutta missään vaiheessa ei pystytty uskottavasti osoittamaan, kuinka tämä tavoite saavutettaisiin.

Olisi korkea aika tehdä ero toisaalta puolueettoman asiantuntijan, toisaalta edunvalvojan eli lobbarin välillä. Se ero ei riipu koulutustasosta, ei myöskään esillä olevaan kysymykseen 
liittyvän tutkitun faktatiedon hallinnasta, vaan siitä, mitä tietoja päättäjille tarjotaan. Oikeudessa todistaja joutuu kunnian ja omantunnon kautta antamaan vakuutuksen, jonka mukaan "minä todistan ja kerron kaiken totuuden tässä asiassa siitä mitään salaamatta tai siihen mitään lisäämättä taikka sitä muuttamatta”. Sama periaate sopisi myös lainsäädännön valmistelussa ja eduskunnan päätösprosessissa kuultujen asiantuntijoiden ohjenuoraksi. Ongelma on erityisesti kohta "siitä mitään salaamatta". Tutkimustiedon määrä on nimittäin valtava, eikä kukaan voi hallita siitä kuin pienen osan. Jos asiantuntijan toimeksiantaja on etujärjestö, yritys tai kansalaisjärjestö, hän voi tiedon valtamerestä poimia sellaiset muruset, jotka tukevat hänen ajamaansa asiaa, mutta tiedostamatta tai tahallaan jättää huomiotta toisenlaista näkökantaa tukevat löydökset. Lobbarit ovatkin valikoidun tutkimustiedon suurkuluttajia, ja tästä syystä puolueettomille asiantuntijoille tulisi antaa suurempi paino.

\section{EDUSKUNNAN KAISTAPÄISET KÄYTÄNNÖT}

Sote-uudistuksen kuolinkamppailu käytiin eduskunnan perustuslaki- sekä sosiaali- ja terveysvaliokunnassa. Perustuslakivaliokunnasta on muodostunut erikoinen istuin, joka jakelee tuomioita lakiesityksistä pienen oikeustieteilijöiden joukon sanelemien tulkintojen perusteella. Sosiaali- ja terveysvaliokunta teki kevään 2019 mittaan varmaan ylityöennätyksen, sillä sote-lakien perkauksessa se kuuli yli tuhatta asiantuntijaa. Tällaisen lauman marssittamisessa eduskuntaan ei ole järkeä, sillä yksikään kansanedustaja ei varmasti kyennyt muodostamaan valistunutta kantaansa niin monen "asiantuntijan" tarjoamasta sirpaletiedon sillisalaatista. Lisäksi tarjolla oli suuri määrä kirjallista materiaalia, niin että valiokunnan jäseniä ei uutiskuvissa juuri näkynyt paperipinojen takaa.

Helsingin Sanomat teki selvityksen eduskunnan käyttämistä asiantuntijoista vuosilta 19982013. Heidän kokonaismääränsä oli 85200 eli noin 5600/vuosi! Noin kaksi kolmasosaa edusti elinkeinoelämän, palkansaajien ja maatalouden etujärjestöjä, noin joka kymmenes kansalaisjärjestöjä. Työnantajien leivissä oli kaksi kertaa enemmän kuin palkansaajien, mutta puolueettomia tieteellisiä asiantuntijoita ei selvityksessä edes mainittu.
Vaikka avoin korruptio on Suomessa vähäistä, niin hiljattain julkaistun väitöskirjatutkimuksen mukaan (7) lobbauksessa sijoitumme kansainväliseen kärkeen. Toimeksiantajat panostavat vuosittain yhteensä noin 120 euroa/kansalainen, mikä on enemmän kuin USAssa, eikä varmasti ole hukkaan heitettyä rahaa. Elinkeinoelämän järjestöjen ja yritysten piilovaikuttamista lainsäädäntöön onkin pidetty suomalaisen demokratian epäterveenä piirteenä.

\section{KUINKA NÄYTTÖÖN PERUSTUVAA PÄ̈TÖKSENTEKOA VOIDAAN PARANTAA?}

Ministeriöt ovat avainasemassa, koska hyvä valmistelu on hyvän lainsäädännön ja hyvien hallintokäytäntöjen edellytys. Valtioneuvoston kanslialla on koordinoiva rooli, ja sen TEA-työryhmä (tutkimus, ennakointi, arviointi) vastaa myös merkittävien tutkimukseen tarkoitettujen resurssien käytön suunnittelusta ja ohjauksesta. Se valmistelee Suomen Akatemian strategisen tutkimuksen priorisointipäätökset (55 miljoonaa euroa/vuosi), ja päättää valtioneuvoston omien tutkimusvarojen käytöstä (noin 10 miljoonaa euroa/ vuosi). Työryhmässä on edustaja kustakin ministeriöstä, ja heiltä tulisi edellyttää pätevyyttä tutkimuksen arvioinnissa, tilaamisessa ja hankkeiden seurannassa. Tohtorin tutkinnon suorittanut tutkimusjohtaja jokaisessa ministeriössä ei ole kohtuuton vaatimus.

Laajan ja laadultaan vaihtelevan tutkimustiedon jalostaminen maallikkopäättäjien käyttöön edellyttää systemaattisia katsauksia, joiden laadinnassa tarvitaan riippumatonta asiantuntemusta. Sitä löytyy parhaiten kansallisista tiedeakatemioista, jotka valitsevat jäsenensä vain tieteellisen pätevyyden perusteella. Englannissa maailman vanhin tiedeakatemia, Royal Society, antoi ensimmäisen raporttinsa kuninkaalle jo vuonna 1667 - se muuten käsitteli nykyisinkin ajankohtaista kysymystä metsien käytöstä. Yhdysvalloissa kansallisilla tiedeakatemioilla on lakisääteinen velvoite antaa tutkimukseen perustuvaa neuvontaa mille tahansa valtionhallinnon elimelle. EU:n komissio on perustanut uuden tiedeneuvontamekanismin, jota ohjaa seitsenhenkinen neuvonantajaryhmä, mutta asiantuntemus tulee kansallisilta tiedeakatemioilta. Niiden yhteistyöelin EASAC (European Academies Science Advisory Committee) on jo useiden vuosien ajan 
laatinut systemaattisia katsauksia ajankohtaisiin politiikan teemoihin. Suomessa valtioneuvoston kanslia on antanut maan neljän tiedeakatemian yhteistyöelimelle kolmivuotisen määrärahan suomalaisen tiedeneuvontajärjestelmän suunnittelua ja perustamista varten.

Kansalaisilla on oikeus saada tietoa siitä, mitä tietolähteitä ja minkälaisia asiantuntijoita lainvalmistelussa ja valiokuntien mietinnöissä on käytetty, joten nämä tulisi kirjata näkyviin. Suomeen olisi myös perustettava lobbarirekisteri, jollainen jo toimii monissa maissa ja myös Euroopan Unionissa. Päätöksenteon avoimuus edellyttää tietoa siitä, minkälaiset asiantuntijat ja intressitahot ovat osallistuneet valmisteluun.

\section{LOPUKSI}

Viime vuosina yleistyneet sanat "totuuden jälkeinen aika" ja "valeuutiset" kuvaavat tiedonvälityksen jättimäisiä ongelmia. Huuhaa leviää kulovalkean tavoin, ihmiset sulkeutuvat some-kupliin, joita perustellut faktat eivät puhkaise. Poliitikot laskevat suustaan löysää puhetta ja suoranaisia valheita, mutta äänestäjät veisaavat viis! Media panee samalle viivalle kokeneen ravitsemustutkijan ja itse keksittyä ihmedieettiä markkinoivan rääväsuun. Hopeavesi hakkaa rokotteet, jo voitetut tartuntataudit kuten tuhkarokko valtaavat alaa. Tiedeyhteisön edustajilta näyttää joskus usko loppuvan, kun tutkittu tieto ja perustellut argumentit jyrätään.

Silti ei pidä antaa periksi! Kaiken hälyn ja hössötyksen taustalla on kuitenkin reaalimaailma ja totuus, jota tutkijat pyrkivät lähestymään ja myös välittämään kansalaisille. Tiedeyhteisön velvollisuus on huolehtia siitä, että tyhmän päätöksen tehneet poliitikot eivät koskaan voi vetäytyä vastuusta sillä perusteella, että me emme tienneet!

\section{LÄHTEET}

(1) Raivio K. Näytön paikka. Tutkimustiedon käyttö ja väärinkäyttö. Helsinki: Gaudeamus; 2019.

(2) Kahneman D. Ajattelu, nopeasti ja hitaasti. Suom. Kimmo Pietiläinen. Helsinki: Terra Cognita; 2012.

(3) Raivio K. Näyttöön perustuva päätöksenteko - suomalainen neuvonantojärjestelmä.

Valtioneuvoston kanslian raporttisarja 3/2014.

(4) Intergovernmental Panel for Climate Change. Climate Change 2014: Synthesis Report. Geneva: IPCC; 2014

(5) Duodecim. Terveysportti. <terveysportti.fi>

(6) Tieteen tiedotus ry. Tiedebarometri 2016. Tutkimus suomalaisten suhtautumisesta tieteeseen ja tieteellis-tekniseen kehitykseen. $<$ tieteentiedotus.fi/files/Tiedebarometri_2016. pdf>

(7) Blom A. Taloudelliset eturyhmät politiikan sisäpiirissä. Tutkimus liike-elämän poliittisesta vaikuttamisesta kolmikantaisessa Suomessa 1968-2011. Turun yliopiston julkaisuja, C:454. Turku: Turun yliopisto; 2018.

\section{KARI RAIVIO \\ Kansleri (emeritus) \\ Helsingin yliopisto}

